\title{
KOMPOSISI ASAM LEMAK CACING LAUT SIASIA (Sipunculus, SP) DARI PERAIRAN PANTAI PULAU NUSALAUT
}

\author{
Bernita Br Silaban \\ Jurusan Teknologi Hasil Perikanan, FPIK Unpatti - Ambon \\ E-mail: ita_borju@yahoo.com
}

\begin{abstract}
Background: "Siasia" is a seaworm species in the phylum that includes Sipuncula Sipunculidea class. This animal has been consumed for generations by coastal communities Nusalaut Island, central mollucas but not yet universally known. Until now there has been obtained gisi complete composition. This study aimed to identify the composition of fatty acids contained in vain fresh seaworms.

Method: Seaworms vain taken from coastal waters of Negeri Titawaai and Nalahia Nusalaut Island, Central Moluccas in March 2014. The parameters analyzed include methods is sokhlet fat content and fatty acid by GC method.

Result: The results showed fresh siasia fat content $1.12 \%$ of coastal waters Titawaai while $1.91 \%$ of coastal waters Nalahia. Fatty acids seaworms were identified from coastal waters Titawai is kaparat acid (C10: 0), lauric acid (C12: 0), myristic acid (C14: 0), palmitoleic acid (C16: 1), stearic acid (C18: 0 ), linolenic acid (C18: 3 ) acid and eicosapentaenoic (C20:5) while the fatty acids of seaworm vain of coastal waters Nalahia include is lauric acid (C12: 0), myristic acid (C14: 0), palmitoleic acid ( C16: 1), stearic acid (C18: 0) and eicosapentaenoic acid (C20: 3).

Conclusion: Siasia fatty acid from Titawai waters of the identified seven seas of each capsic acid (C10: 0), lauric acid (C12: 0), myristic acid (C14: 0), palmitoleic acid (C16: 1), Stearic acid (C18: 0), linolenic acid (C18: 3 ) and eicosapentaenoic acid (C20:5) whereas Siasia fatty acids from Nalahia's coastal waters were identified as five lauric acid (C12:0), myristic acid (C14:0), palmitoleic acid (C16: 1), stearic acid (C18: 0) and eicosapentaenoic acid (C20: 3).
\end{abstract}

Key word: fatty acid, seaworms, Nusalaut Island

\section{Abstrak}

Latar Belakang: "Siasia" adalah spesies cacing laut yang termasuk dalam Filum Sipuncula kelas Sipunculidea. Hewan ini telah dikonsumsi secara turun temurun oleh masyarakat pesisir Pulau Nusalaut, Maluku Tengah namun belum dikenal secara umum. Hingga kini belum diperoleh komposisi gisi secara lengkap. Penelitian ini bertujuan untuk mengidentifikasi komposisi asam lemak yang terkandung pada cacing laut siasia segar.

Metode: Cacing laut siasia di ambil dari perairan pantai Nalahia dan Titawaai Pulau Nusalaut, Maluku Tengah pada bulan Maret 2014. Parameter yang dianalisa meliputi kadar lemak dengan metode sokhlet dan asam lemak dengan metode GC.

Hasil: Hasil penelitian menunjukkan kadar lemak cacing laut siasia segar sebesar 1,12\% dari perairan pantai Titawaai sedangkan $1,91 \%$ dari perairan pantai Nalahia. Asam lemak cacing laut yang teridentifikasi dari perairan pantai Titawai antara lain asam lemak kaparat $\left(\mathrm{C}_{10}: 0\right)$, asam laurat $\left(\mathrm{C}_{12}: 0\right)$, asam miristat $\left(\mathrm{C}_{14}: 0\right)$, asam palmitoleat $\left(\mathrm{C}_{16}: 1\right)$, asam stearat $\left(\mathrm{C}_{18}: 0\right)$, asam linolenat $\left(\mathrm{C}_{18}: 3\right)$ dan asam eikosapentaenoat $\left(\mathrm{C}_{20}: 5\right)$ sedangkan asam lemak cacing laut yang teridentifikasi dari perairan pantai Nalahia antara lain asam laurat $\left(\mathrm{C}_{12}: 0\right)$, asam miristat $\left(\mathrm{C}_{14}: 0\right)$, asam palmitoleat $\left(\mathrm{C}_{16}: 1\right)$, asam stearat $\left(\mathrm{C}_{18}: 0\right)$ dan asam eikosapentaenoat $\left(\mathrm{C}_{20}: 3\right)$.

Kesimpulan: Asam lemak cacing laut siasia dari perairan pantai negeri Titawai yang teridentifikasi sebanyak tujuh masing-masing asam kaparat $\left(\mathrm{C}_{10}: 0\right)$, asam laurat $\left(\mathrm{C}_{12}: 0\right)$, asam miristat $\left(\mathrm{C}_{14}: 0\right)$, asam palmitoleat $\left(\mathrm{C}_{16}: 1\right)$, asam stearat $\left(\mathrm{C}_{18}: 0\right)$, asam linolenat $\left(\mathrm{C}_{18}: 3\right)$ dan asam eikosapentaenoat $\left(\mathrm{C}_{20}: 5\right)$ sedangkan asam lemak siasia dari perairan pantai negeri Nalahia yang teridentifikasi sebanyak lima masing-masing asam laurat $\left(\mathrm{C}_{12}: 0\right)$, asam miristat $\left(\mathrm{C}_{14}: 0\right)$, asam palmitoleat $\left(\mathrm{C}_{16}: 1\right)$, asam stearat $\left(\mathrm{C}_{18}: 0\right)$ dan asam eikosapentaenoat $\left(\mathrm{C}_{20}: 3\right)$.

Kata kunci: asam lemak, cacing laut siasia, Pulau Nusalaut 


\section{PENDAHULUAN}

Pulau Nusalaut adalah salah satu wilayah yang terletak di Maluku Tengah dimana penduduk aslinya sebagian besar masyarakat pesisir yang kehidupannya mendapat pengaruh kondisi laut, meskipun tidak bergantung penuh pada laut. Pulau Nusalaut terdapat tujuh negeri yaitu Nalahia, Ameth, Akkon, Abubu, Titawai, Sila dan Leinitu. Dalam kegiatan produksi mereka memanfaatkan sumberdaya hayati di lingkungan darat maupun perairan laut untuk memenuhi kebutuhan ekonomi (subsisten dan komersial), yang umumnya masih tradisional, sederhana dan belum optimal, seperti ikan, molusca dan kerang-kerangan. Ada pula sumberdaya perairan pantai yang sudah lama dimanfaatkan masyarakat setempat namun masih unik dan khas yaitu spesies cacing laut dengan sebutan "siasia"dari Filum Sipuncula kelas Sipunculidea.

Berbeda dengan cacing laut lainnya, cacing laut atau yang disebut siasia, biasanya hidup di daerah pesisir terutama di sekitar area padang lamun, hutan mangrove dan terumbu karang. Biota ini cenderung mendiami dasar perairan terlebih khusus di dalam substrat sehingga dikategorikan sebagai organisme bentik bersifat infauna. Cacing laut siasia mampu menghuni daerah bersubstrat lunak maupun keras. Pada substrat lunak, biota ini cenderung menguburkan diri di daerah berpasir dan berlumpur seperti pada kelas kerangkerangan. Sedangkan pada substrat keras, Cacing laut siasia mampu hidup di antara celah-celah karang dan juga menghuni cangkang gastropoda dan tabung kosong bekas tempat hidup polychaeta (Cutler, 1994). Bagi masyarakat yang hidup di pesisir pantai Pulau Nusalaut, Maluku Tengah hewan ini sudah menjadi lauk pengganti ikan manakala musim paceklik tiba. Umumnya digoreng, ditumis dikecap, disate, ataupun dimakan mentah dengan campuran asam jeruk. Namun sampai saat ini pemanfaatannya belum optimal bahkan belum dikenal luas jika dibandingkan dengan cacing laor dari kelas polychaeta yang sudah diketahui pemanfaatannya.

Penelitian yang baru dilakukan terhadap cacing laut siasia hanya mengkaji biologi dan morfologi diantaranya: Catatan kecil tentang sia-sia, cacing laut yang dikonsumsi
(Pradina, 1993);Sipuncula: Biota laut yang kontrovertif (Pamungkas, 2010) Studi etnobiologi, etnoteknologi dan pemanfaatan kekuak (Xenosiphon sp.) oleh masyarakat di Kepulauan Bangka-Belitung (Fakhrurrozi, 2011) sedangkan kajian ilmiah tentang komposisi kimia secara lengkap belum diperoleh. Silahooy, (2008) melaporkan cacing laut siasia dari perairan negeri Ouw Pulau Saparua Kab. Maluku Tenggah teidentifikasi mengandung 4 jenis asam lemak yaitu: asam miristat, palmitat, arakidonat dan linolenat. Silaban, (2012) juga melaporkan cacing laut siasia dari perairan pantai pulau Nusalaut memiliki kandungan gizi karbohidrat, protein, lemak, vitamin $A, B_{1}, B_{6}, B_{12}$ dan $E$ serta mineral $P$, $\mathrm{I}_{2}$, Ca, Mg dengan komposisi yang berbeda sesuai dengan asal perairan. Diduga cacing laut siasia dari perairan Pulau Nusalaut juga mengandung asam lemak.

Asam lemak merupakan asam organik berantai panjang yang mempunyai gugus karboksil $(\mathrm{COOH})$ di salah satu ujungnya dan gugus metil $(\mathrm{CH} 3)$ di ujung lainnya. Asam lemak memiliki fungsi yang penting bagi tubuh manusia, antara lain linoleat (omega-6) dan linolenat (omega-3) yang digunakan untuk menjaga bagian bagian struktural dari membran sel, serta mempunyai peranan penting dalam perkembangan otak. Asam lemak omega-3 dapat menyembuhkan aterosklerosis, mencegah kanker, diabetes dan memperkuat sistem kekebalan tubuh (Imre dan Saghk 1997). Asam linolenat memiliki turunan eikosapentaenoat (EPA) dan dokosaheksaenoat (DHA) yang sangat dibutuhkan oleh tubuh manusia karena memiliki beberapa manfaat yaitu dapat mencerdaskan otak, membantu masa pertumbuhan dan menurunkan kadar trigliserida (Leblanc et al. 2008). Pemenuhan kebutuhan asam lemak bagi tubuh dapat diperoleh dengan cara mengonsumsi bahan pangan baik yang berasal dari tumbuhan (mineral nabati) maupun hewan (mineral hewani) yang berasal dari darat ataupun dari laut. Biota perairan diketahui banyak mengandung asam lemak tak jenuh majemuk atau lebih dikenal dengan polyunsaturated fatty acids (PUFA). Omega 3-PUFA, Eicosapentaenoic acid (EPA) dan Docosahexaenoic acid (DHA) memegang peranan penting terhadap penyakit 
kardiovaskular, meningkatkan kemampuan belajar dan peningkatan sistem imun tubuh (Freije dan Awadh 2010). Informasi mengenai kandungan asam lemak perlu diketahui, untuk dapat mengevaluasi asupan makanan dan kecukupan asam lemak dari bahan pangan yang berasal dari laut. Penelitian ini bertujuan untuk mengidentifikasi komposisi asam lemak yang terkandung pada cacing laut siasia dari perairan pantai Pulau Nusalaut.

\section{MATERI DAN METODE PENELITIAN Alat dan Bahan}

Alat yang digunakan adalah waskom, sterofoam, pisau, talenan, penirisan, timbangan analitik, blender, corong, pompa vakum, erlemeyer, gelas ukur, pipet, tabung reaksi, hot plate, cawan porselin, desikator, seperangkat alat GC dan alat kimia lainnya. Bahan utama yang digunakan dalam penelitian ini adalah daging cacing laut siasia segar dari perairan pantai Nalahia dan Titawai, Pulau Nusalaut, es batu, kantong plastik, spidol dan bahan-bahan kimia antara lain aquades, $\mathrm{H}_{2} \mathrm{SO}_{4}$, asam borat, metanol, $\mathrm{NaOH}, \mathrm{HCl}$, diethyl ether, petroleum ether, $\mathrm{Na}_{2} \mathrm{SO}_{4}$ anhidrat dan bahan kimia lainnya.

\section{Prosedur Kerja}

Sampel yang diperoleh dari masingmasing perairan dibersihkan dengan cara dibelah kemudian isi perut dikeluarkan, dicuci bersih, dimasukkan dalam kantong plastik, diberi lebel sesuai dengan kode, dimasukkan dalam sterofoam yang berisi hancuran es untuk tujuan analisa.

Parameter yang dianalisis meliputi kadar lemak dengan metode sokhlet (AOAC, 2005) dan asam lemak dengan metode GC. Analisis Profil Asam Lemak (AOAC 2005). Profil asam lemak dapat ditentukan dengan metode gas kromatografi. Analisis asam lemak diawali dengan menghidrolisis lemak/minyak dalam sampel (daging cacing siasia) menjadi asam lemak, kemudian ditransformasi menjadi bentuk esternya yang bersifat lebih mudah menguap. Transformasi dilakukan dengan cara metilasi menggunakan water bath sehingga diperoleh metal ester asam lemak (FAME). Kemudian FAME dianalisis dengan alat kromatografi gas. Identifikasi dilakukan dengan membandingkan waktu retensinya dengan standar (Supelco 37 FAME) pada kondisi analisis yang sama. Waktu retensi dihitung pada kertas rekorder sebagai jarak dari garis pada saat muncul puncak pelarut sampai ke tengah puncak komponen yang dipertimbangkan. Dalam penelitian ini dilakukan pengukuran paremeter fisik kimia tempat cacing laut sia-sia meliang meliputi suhu, salinitas, dan $\mathrm{pH}$. Hasil yang diperoleh ditampilkan dalam bentuk tabel dan gambar.

\section{Waktu dan Tempat Penelitian}

Penelitian ini berlangsung pada bulan Maret 2014 perairan Nalahia dan Titawaai pulau Nusalaut Kabupaten Maluku Tengah. Analisis asam lemak dilakukan di Laboratorium Teknologi Pengolahan Hasil Pertanian (TPHP) Universitas Gajah Mada, Yogjakarta.

\section{HASIL DAN PEMBAHASAN \\ Kandungan Lemak Siasia segar dari perairan pantai Titawaai dan Nalahia}

Kandungan lemak siasia yang berasal dari perairan pantai Titawaai dan Nalahia dapat dilihat pada Tabel 1. Hasil analisis menunjukkan bahwa kadar lemak dari siasia yang berasal dari perairan pantai Titawaai sebesar $1,12 \%$ lebih kecil dibandingkan dari perairan Nalahia 1,91\%. Kandungan lemak ini jauh lebih besar dibandingkan dengan kandungan lemak siasia dari perairan Nalahia dan Titawai masing-masing 0,22\% dan 0,27\% (Silaban ${ }^{a}$, 2012) Titawai, Abubu dan Akoon masing-masing 0,44\%, 0,34\%, $0,38 \%$ (Silaban ${ }^{b}, 2012$ ), kekuak segar dari perairan Pabuar Bangka sebesar 0,18\% (Fakhrurrozi, 2011) namun lebih kecil dari siasia asal perairan Pantai Ouw Pulau Saparua 3,39\% (Silahooy, 2008). Perbedaan kandungan ini dapat dipengaruhi oleh musim dan asal perairan. Menurut Edison, (2010) kandungan lemak ikan tergantung pada spesies, makanan, asal, musim serta umurnya. 
Tabel 1. Perbandingan Kandungan Lemak Hasil Penelitian Dengan Beberapa Hasil Penelitian Dari Perairan Pulau Nusalaut

\begin{tabular}{lccc}
\hline \multirow{2}{*}{ Asal perairan } & \multicolumn{3}{c}{ Kandungan lemak (\%) } \\
\cline { 2 - 4 } Titawai & $\mathbf{A}$ & $\mathbf{b}$ & $\mathbf{C}$ \\
Nalahia & 1,12 & 0,27 & 0,44 \\
Abubu & 1,91 & 0,22 & - \\
Akoon & - & - & 0,68 \\
Ket: a. Hasil penelitian & b. Silaban B ${ }^{a}(2012)$ & c. Silaban B ${ }^{b},(2012)$ \\
-: tidak dianalisa & & &
\end{tabular}

\section{Profil Asam Lemak cacing laut Siasia}

Hasil analisis profil asam lemak siasia menggunakan kromatogragi gas teridentifikasi masing-masing tujuh asam lemak dari perairan pantai Titawaai dan lima asam lemak dari perairan pantai Nalahia. Tujuh puncak yang teridentifikasi dari perairan pantai Titawai adalah: asam kaparat (C10:0), asam laurat (C12:0), asam miristat (C14:0), asam palmitoleat (C16:1), asam stearat (C18:0), asam linolenat (C18:3) dan asam eikosapentaenoat (C20:3). Keragaman asam lemak tersebut terdiri dari 4 asam lemak jenuh (saturated fatty acid = SAFA) yaitu masing masing asam kaparat, laurat, miristat, dan stearat serta 3 asam lemak tak jenuh yaitu 2 asam lemak tak jenuh ganda (polyunsaturated fatty acid = PUFA) masing-masing asam linoleat dan asam eukosapentaenoat dan 1 asam lemak tak jenuh tunggal ( monounsaturated fatty acid $=$ MUFA) yaitu asam palmitoleat. Satu dari tiga asam lemak tak jenuh merupakan kelompok dari omega 3 (asam eikosapentanoat), sedangkan asam linoleat merupakan kelompok dari omega 6 . Sedangkan lima puncak yang teridentifikasi dari perairan pantai Nalahia adalah: asam laurat (C12:0), asam miristat (C14:0), asam palmitoleat (C16:1), asam stearat (C18:0) dan asam eikosapentaenoat (EPA) (C20:5). Hasil perhitungan persentase relative keragamaman asam lemak tersebut terdiri atas 3 asam lemak jenuh (saturated fatty acid = SAFA) masing-masing asam laurat, miristat, stearat dan 2 asam lemak tak jenuh yaitu 1 asam lemak tak jenuh tunggal ( monounsaturated fatty acid = MUFA) yaitu asam palmitoleat dan 1 asam lemak tak jenuh ganda (polyunsaturated fatty acid = PUFA) yaitu asam eukosapentaenoat. Komposisi asam lemaknya dapat dilihat pada Tabel 2.

Tabel 2. Kandungan Asam Lemak Sia-Sia dari Perairan Pantai Pulau Nusalaut Maluku Tengah.

\begin{tabular}{lccc}
\hline \multirow{2}{*}{ Asam lemak } & \multirow{2}{*}{ Simbol } & \multicolumn{2}{c}{ Perairan pantai } \\
\cline { 3 - 4 } & & Titawai (\%) & Nalahia (\%) \\
\hline Jenuh & C10: 0 & 0,18 & - \\
Kaprat & C12: 0 & 1,63 & 0,23 \\
Laurat & C14: 0 & 2,55 & 5,33 \\
Miristat & C18: 0 & 62,81 & 23,37 \\
Stearat & & & \\
\hline Tak jenuh & C16: 1 & 15,80 & 9,56 \\
Palmitoleat & C18: 2 & 5,33 & - \\
Linoleat & C20: 5 & 1,13 & 3,38 \\
EPA & & & \\
\hline
\end{tabular}

Rata-rata kandungan asam lemak jenuh dari dari kedua perairan ini relative tinggi dibandingkan dengan asam lemak tak jenuh. Kandungan asam lemak jenuh total dari perairan pantai Titawai sebesar $67,17 \%$ dan tak jenuh total sebesar 22,26\%. Kandungan asam lemak jenuh total dari perairan pantai Nalahia sebesar $28,93 \%$ dan tak jenuh total sebesar $12,94 \%$. Hal ini disebabkan karena asam lemak tidak jenuh lebih mudah 
dimetabolisme dibandingkan dengan asam lemak jenuh (Edison, 2010). Rata-rata persentase kandungan asam lemak siasia dari perairan pantai Titawai lebih besar dibandingkan perairan pantai Nalahia. Besarnya komposisi asam lemak tak jenuh siasia di perairan Titawai disebabkan karena ketersediaan nutrisi dan kondisi ekosistem perairan Titawai lebih baik dan beragam seperti mangrove, lamun dan beberapa sungai yang memberikan kontribusi nutrisi bagi perairan sebagai pembawa zat-zat hara serta pelarut gas-gas dan zat mineral dari darat berupa material yang berasal dari hewan dan tumbuhan dari darat, terdeposisi melalui proses pembusukan oleh bakteri dalam bentuk sedimen dan pada akhirnyan dimanfaatkan oleh hewan laut seperti siasia sebagai sumber makanan.

Tabel 2 memperlihatkan kandungan asam lemak jenuh tertinggi sampai terendah berturut-turut adalah asam stearate > miristat $>$ laurat $>$ kaprat. Kandungan asam stearat (C18:0) mendominasi asamlemak jenuh pada daging siasia dari perairan pantai Titawai dan Nalahia sebesar $63,81 \%$ dan $23,37 \%$ lebih tinggi dari daging cacing laut siasia perairan Ouw Pulau Saparua sebesar $11,61 \%$ (Silahooy, 2008); kerang bulu (Abdullah, dkk 2013) sebesar 3,35\%; abalone (Haliotis sp.) Mateos et al. (2010) sebesar 0,80\%; kerang simping sebesar 2,07\% Subhan, (2014). Asam stearat merupakan asam lemak jenuh dengan berat molekul tertinggi dan terdapat pada biji-bijian serta minyak hewan laut dalam jumlah yang sedikit. Asam stearat dapat menyebabkan trombogenik atau pembekuan darah, hipertensi, kanker dan obesitas (Mateos et al. 2010). Kandungan asam lemak miristat (C14:0) pada daging siasia dari perairanpantai Titawai dan Nalahia adalah sebesar $2,55 \%$ dan $5,33 \%$ lebih tinggi dari daging cacing laut siasia perairan Ouw Pulau Saparua sebesar 2,31\% Silahooy, (2008); kerang bulu (Abdullah, dkk 2013) sebesar 1,75\%; abalone (Haliotis sp.) Mateos et al. (2010) sebesar 0,90\% dan kerang simping Subhan, (2014) sebesar $0,24 \%$. Perbedaan nilai asam miristat dapat disebabkan oleh spesies, ketersediaan pakan, umur, asal perairan dan ukuran sampel yang digunakan. Asam miristat terdapat dalam jumlah yang sedikit, tidak lebih dari kisaran 1-2\%. Asam miristat dapat dimanfaatkan dalam pembuatan shampo, krim, kosmetik dan flavor makanan. Asam miristat dibutuhkan dalam retina dan photoreseptor (Abdullah, dkk 2013). Kandungan asam laurat (C12:0) pada daging cacing laut siasia dari perairan pantai Titawai dan Nalahia adalah sebesar $1,63 \%$ dan $0,23 \%$ lebih tinggi dari daging kerang bulu (Abdullah, dkk 2013) sebesar 0,02\%; pada kerang simping Subhan, (2014) sebesar $0,05 \%$. Asam laurat sebagai monogliserida biasa digunakan dalam industri pharmaceutical sebagai antibakteri, antivirus dan anti protozoa serta digunakan juga dalam industri sabun dan kosmetik. Asam laurat bertanggungjawab terhadap naiknya LDL darah dan berhubungan dengan serangan jantung (Abdullah, $d k k$ 2013).

Kandungan asam lemak tak jenuh tunggal palmitoleat pada pada daging cacing siasia tergolong lebih besar dari asam lemak tidak jenuh majemuk (PUFA) lainnya yaitu linoleat dan EPA Kandungan asam palmitoleat (C16:1) pada daging cacing laut siasia dari perairan pantai Titawai dan Nalahia sebesar $15,80 \%$ dan $9,56 \%$ lebih tinggi dari daging kerang bulu (Abdullah, $d k k$ 2013) sebesar 2,42\%; abalone (Haliotis sp.) sebesar 0,30\% (Mateos et al. 2010); dan kerang simping sebesar $0,24 \%$ (Subhan, 2014). Perbedaan ini disebabkan oleh perbedaan komposisi jenis lemak yang dikonsumsi dari lingkungan hidupnya (Leblanc et al. 2008). Selain itu juga dipengaruhi oleh suhu dan habitatnya. Guderley et al. (2007), Kerang yang berhabitat pada perairan yang memiliki suhu yang rendah $\left(4-9^{\circ} \mathrm{C}\right)$, yaitu Mytilus edulis memiliki kandungan asam lemak tidak jenuh yang lebih tinggi, terutama PUFA 53,5\%. Suhu rendah dapat meningkatkan daya larut oksigen sehingga meningkatkan sintesis asam lemak.

Hasil pengukuran parameter suhu lingkungan dari perairan pantai Titawai dan Nalahia tempat cacing laut siasia meliang berkisar antara $28-30,5^{\circ} \mathrm{C}, \mathrm{pH} 7$, dan salinitas $26-34 \%$ (Tabel 3 ) kisaran tersebut masih berada pada kisaran yang normal untuk kehidupan cacing laut siasia. Berdasarkan hasil pengamatan sedimen secara visual tipe substrat pada lokasi tempat siasia meliang adalah pasir, pasir berlumpur, pasir berbatu dan patahan 
karang mati sehingga merupakan tempat hidup yang baik untuk cacing laut siasia. Suhu perairan memegang peranan penting untuk mengukur proses alamiah organisme akuatik, baik metabolisme untuk pertumbuhan, fisiologi dan reproduksinya.
Salinitas dipengaruhi oleh beberapa faktor antara lain curah hujan, aliran air tawar yang masuk ke laut melalui sungai dan evaporasi. Hal ini ditunjukkan dengan terdapatnya beberapa mata air tawar yang berasal dari pegunungan di pinggiran pantai.

Tabel 3. Pengukuran Paremeter Lingkungan Tempat Sia-Sia Meliang.

\begin{tabular}{cccclc}
\hline Lokasi & $\mathrm{pH}$ & $\begin{array}{c}\text { Suhu } \\
\left({ }^{\circ} \mathrm{C}\right)\end{array}$ & Salinitas $(\%)$ & \multicolumn{2}{c}{ Substrat } \\
\hline Titawai & 7 & $29-30,5$ & $26-30$ & $\begin{array}{l}\text { Pasir, pasir berbatu, pasir berlumpur, } \\
\text { patahan karang mati }\end{array}$ \\
\hline Nalahia & 7 & $28-29$ & $30-34$ & $\begin{array}{l}\text { Pasir puth panjang, berbatu, patahan } \\
\text { karang dan pasir berlumpur }\end{array}$ \\
\hline
\end{tabular}

Kandungan asam lemak linoleat pada daging cacing laut siasia dari perairan pantai Titawai sebasar $5,33 \%$, lebih rendah dari daging cacing laut siasia perairan Ouw Pulau Saparua sebesar 13,33\% (Silahooy, 2008); abalone (Haliotis sp.) hasil penelitian Mateos et al. (2010) sebesar 16,60\%; lebih tinggi dari daging kerang bulu (Abdullah, $d k k$ 2013) sebesar $0,63 \%$ dan kerang simping hasil penelitian Subhan, (2014) sebesar 0,19\%. Perbedaan tersebut dapat disebabkan oleh ketersediaan pakan, habitat, asal perairan dan suhu perairan (Guderley et al. 2007). Tidak terdeteksi kandungan linoleat pada perairan pantai Nalahia berkaitan dengan rantai makanan yang dikonsumsi oleh siasia. Siasia memakan fitoplankton. Terdapat kemungkinan bahwa pakan yang dikonsumsi oleh siasia sedikit mengandung linoleat sehingga saat dilakukan ekstrak hasil yang diperoleh sangat kecil dan tidak terbaca dalam kromatogram. Asam linoleat merupakan asam lemak esensial penting bagi tubuh manusia. Asam linoleat ditemukan dalam jaringan kulit manusia, berperan memelihara kelembaban jaringan epidermis kulit dan meminimalkan hilangnya penguapan air dari epidermis. Kekurangan asam linoleat dapat menyebabkan kulit kering dan bersisik karena terlalu banyak cairan yang keluar dari kulit. Selain itu asam linoleat berperan dalam pertumbuhan, pemeliharaan membran sel, pengaturan metabolisme kolesterol, dan menurunkan tekanan darah (Subhan, 2014).

Kandungan EPA pada daging siasia dari perairan pantai Titawai dan Nalahia adalah sebesar $1,13 \%$ dan $3,38 \%$ berbeda dari daging kerang bulu (Abdullah, dkk 2013) sebesar $5,25 \%$ dan abalone (Haliotis sp.) hasil penelitian Mateos et al. (2010) sebesar 9,10\% dan kerang simping Subhan, (2014) sebesar $1,45 \%$. Perbedaan nilai EPA ini diduga disebabkan oleh perbedaan spesies, ketersediaan pakan, umur, asal perairan. Ozugul dan Ozugul (2007) menyatakan bahwa keragaman komposisi asam lemak dapat dipengaruhi oleh beberapa faktor yaitu spesies, ketersediaan pakan, umur, habitat dan ukuran; suhu (Subhan, 2014); musim, letak geografis, tingkat kematangan gonad (Edison, 2010).

Cacing laut Siasia bersifat deposit feeder, makanannya sangat bervariasi yaitu berupa partikel-partikel organik yang telah terurai. Makanan cacing laut siasia berupa pasir, lumpur, partikel-partikel kecil dari karang atau batu, fragmen dari alga dan lamun, potongan-potongan kecil dari moluska, bintang laut, diatom dan foraminifera. Kandungan EPA dan DHA yang tinggi pada plankton tersebut dapat meningkatkan kandungan EPA dan DHA pada cacing laut siasia. Suhu perairan yang rendah pun (perairan subtropis) dapat meningkatkan kandungan EPA dan DHA pada cacing laut siasia, plankton dan alga karena dapat meningkatkan daya larut oksigen yang akan mempercepat sintesis asam lemak. Mardiana (2011) menjelaskan sumber pakan alami yang potensial mengandung asam lemak omega 3 adalah fitoplankton, zooplankton, seaweed, oyster, chepalopoda, dan shellfish. Lebih lanjut dikatakan kandungan EPA dan DHA yang tinggi pada plankton sebagai pakan dapat meningkatkan kandungan EPA dan DHA 
Secara umum terlihat bahwa rasio asam lemak omega 6 dan omega 3 pada sia-sia dari perairan Titawai adalah 4,7:1. Asam lemak yang berkualitas baik mempunyai rasio asam lemak omega 6 dan omega 3 yang tidak melebihi 5:1 (sesuai dengan rekomendasi WHO dan FAO dalam Edison 2010). Untuk mempertahankan kesehatan tubuh terutama untuk mencegah penyakit jantung dianjurkan mengkonsumsi omega 6 dan omega 3 dengan rasio 4:1. Dengan demikian daging sia-sia dari perairan pantai Titawai bisa memenuhi standar kecukupan asam lemak bagi tubuh.

\section{KESIMPULAN}

Berdasarkan hasil penelitian dapat disimpulkan bahwa asam lemak cacing laut siasia dari perairan pantai negeri Titawai yang teridentifikasi sebanyak tujuh masingmasing asam kaparat $\left(\mathrm{C}_{10}: 0\right)$, asam laurat $\left(\mathrm{C}_{12}: 0\right)$, asam miristat $\left(\mathrm{C}_{14}: 0\right)$, asam palmitoleat $\left(\mathrm{C}_{16}: 1\right)$, asam stearat $\left(\mathrm{C}_{18}: 0\right)$, asam linolenat $\left(\mathrm{C}_{18}: 3\right)$ dan asam eikosapentaenoat $\left(\mathrm{C}_{20}: 5\right)$ sedangkan asam lemak siasia dari perairan pantai negeri Nalahia yang teridentifikasi sebanyak lima masing-masing asam laurat $\left(\mathrm{C}_{12}: 0\right)$, asam miristat $\left(\mathrm{C}_{14}: 0\right)$, asam palmitoleat $\left(\mathrm{C}_{16}: 1\right)$, asam stearat $\left(\mathrm{C}_{18}: 0\right)$ dan asam eikosapentaenoat $\left(\mathrm{C}_{20}: 3\right)$.

\section{DAFTAR PUSTAKA}

Abdullah A, Nurjanah, Hidayat T, Yusefi V. 2013.Profil asam amino dan asam lemak kerang bulu (Anadara antiquata). Jurnal Pengolahan Hasil Perikanan Indonesia. 16(2): 150-167

AOAC Associaton of Official Analytical Chemist. 2005. Official Methods of Analysis of the Association of Official Analytical Chemist 18 th Edition. Gaithersburg, USA: AOAC International, Inc.

Cutler, E. B. 1994. The sipuncula: their systematic, biology and evolution. Cornell Univ. Press. Ithaca, N.Y. 453p.

Edison 2010. Komposisi asam lemak ikan Nila (Orechromus niloticus) dan Baung (Macrones nemurus) budidaya. Jurnal Pengolahan Hasil Perikanan Indonesia. 13(2): 96-104
Fakhrurrozi, Y. 2011. Studi Etnobiologi, Etnoteknologi Dan Pemanfaatan Kekuak (Xenosiphon sp.) Oleh Masyarakat Di Kepulauan BangkaBelitung. Disertasi. Bogor: PPs. IPB. Hal 1-2-6.

Freije A M, Awadh M N. 2010. Fatty acid compositions of Turbo coronatus Gmelin 1791. British Food Journal 112(10): 1049-1062.

Guderley H, Comeau L, Tremblay R, Pernet F. 2007. Temperature adaptation in two bivalve species from diff erent thermal habitats: enegenics and remodeling of membrane lipid. Journal Experimental Biology 210(2): 2999-3014.

Imre S, Saghk S. 1997. Fatty acid composition and cholesterol content of mussel and shrimp consumed in Turkey. Journal Marine Sciences 3(3): 179-189.

Leblanc JC, Volatier JL, Aouachria NB, Oseredczuk M, Sirot V. 2008. Lipid and fatty acid composition of fish and seafood consumed in France. Journal of Food Composition and Analysis 21(5): 8-16.

Mardiana. 2011. Karakteristik asam lemak dan kolesterol rajungan (Portunus pelagicus) akibat proses pengukusan. [skripsi]. Bogor: Fakultas Perikanan dan Ilmu Kelautan, Institut Pertanian Bogor.

Mateos HT, Lewandowski PA, Su XQ. 2010. Seasonal variations of total lipid and fatty acid contents in muscle, gonad and digestive glands of farmed Jade Tiger hybrid abalone in Australia. Journal Food Chemistry 123(3): 436-441.

Ozogul Y dan Ozogul F. 2007. Fatty acid profiles of commercially important fish species from the mediterranean. Food Chem 100(4):1634-1638.

Pamungkas J. 2010. Sipuncula: Biota Laut yang Kontrovertif. Oseana 35 (1): 7-13.

Pradina, 1993. Catatan Kecil Tentang SiaSia, Cacing Laut Yang Dikonsumsi. LIPI. Ambon. Lonawarta 14 (1) : 47-51.

Silaban, B a. 2012. Profil Nutrisi Sipuncula (Cacing Kacang); Biota laut yang kontrovertif di Pulau Nusalaut, Maluku Tengah. Laporan hasil penelitian dosen pemula yang dibiayai dengan PNBP Lembaga Penelitian Universitas Pattimura.Ambon.

Silaban B b. 2012. Komposisi kimia dan pemanfaatan cacing laut "sia sia" yang 
dikonsumsi masyarakat Pulau Nusalaut Maluku Tengah Jurnal TRITON Jurusan Manajemen Sumberdaya Perairan Fakultas Perikanan dan IImu Kelautan Universitas Pattimura Ambon (2) 1-9 Silahooy V. 2008. Analisa komponen asam amino dan asam lemak dalam cacing laut jenis Sipunculus robustus. [skripsi]. Fakultas Matematika dan IImu
Pengetahuan Alam, Universitas Pattimura. Ambon. Hal 1-79 (tidak dipublikasi).

Subhan R. 2014. Kandungan asam lemak dan kolesterol daging kerang simping (Amusium pleuronectes) segar dan rebus. [skripsi]. Bogor: Fakultas Perikanan dan IImu Kelautan, Institut Pertanian Bogor. Hal 1-30. 